Original Article

\title{
Antibacterial activity of water and ethanol extract of Allium sativum, Curcuma mangga, and Acorus calamus combination
}

\author{
Bayyinatul Muchtaromah*, Mujahidin Ahmad, Romaidi, Lina Ainun Nazilah, Nayla Alin Naja \\ Department of Biology, Faculty of Science and Technology, Universitas Islam Negeri Maulana Malik Ibrahim Malang, Indonesia
}

\begin{abstract}
Madura has been known as an Indonesian tribe that usually used many recipes of traditional medicine in their daily life. One of the medicinal herbs to increase female fertility is the herbal "Subur Kandungan", which consists of garlic (Allium sativum), temu mangga (Curcuma mangga), jeringau (Acorus calamus). The purpose of this study was to determine the phytochemical content and antibacterial activity of $A$. sativum, $C$. mangga and A. calamus combination in water and ethanol solvent against Streptococcus aureus and Escherichia coli. There were three kinds of combinations with different composition ie first combination/C1 (36:36:28); second combination/C2 (40:30:30); third combination/C3 (35:40:45). Clindamycin was as a positive control. The phytochemical screening detected triterpenoids in both extracts, while alkaloids, flavonoids only in ethanol extracts. The highest inhibitory zone of both extracts to $S$. aureus and E. coli were discovered in C3 as strong and moderate inhibition. The most effective MIC value of water extract against $S$. aureus was found on $\mathrm{C} 3\left(9.76 \times 10^{10}\right)$ while ethanol extract was obtained by $\mathrm{C} 1\left(5.9 \times 10^{8}\right)$ at concentrations of $0.39 \%$ and $\mathrm{MBC}$ at $0.78 \%$. The best MIC value of water extract against E. coli was found on $\mathrm{C} 1\left(1.08 \times 10^{10}\right)$ at a concentration of $25 \%$ and $\mathrm{MBC}$ at $50 \%$, whereas ethanol extract was got on $\mathrm{C} 3\left(9.7 \times 10^{9}\right)$ at $0.39 \%$ \& $\mathrm{MBC}$ at $0.78 \%$. It could be concluded that "Subur kandungan" herb recipes could be used as antibacterial drugs, which third combination/C3 in the ethanol solvent is the best treatment compare with others.
\end{abstract}

Keywords: antibacterial, A. Calamus, C. mangga, A. sativum, phytochemical

Received: 14 August 2018 Revised: 31 August 2018 Accepted: 14 October 2018

\section{Introduction}

Staphylococcus aureus is a gram-positive, non-motile bacteria and a normal flora of the skin, nose, gastrointestinal tract and vagina. Escherichia coli is a gram-negative bacteria, a normal flora of the digestive tract that can be found in the vagina during infection. $S$. aureus can infect the reproductive tract with a prevalence rate of $29.8 \%$. E. coli can be a pathogen when it reaches tissues outside of the gastrointestinal tract and becomes one of the causes of reproductive tract infection with a prevalence rate of $13.1 \%$ (Kamazeri et al., 2012).

$S$. aureus and E. coli reported as organisms that are capable to affect aerobic vaginitis (Divya, 2015). Vaginitis occurs due to an imbalance in the growth of normal bacteria characterized by a lack of hydrogen peroxide produced. The condition of vaginitis can have severe consequences of infertility by Lactobacilli. The changes in the $\mathrm{pH}$ of the environment of the vagina cause the inflammatory infections of the vagina and discharge of whitish fluid (Razzak et al., 2011). This occurs because vaginal infections cause advanced infection of the portio, cervix, endometrium, and oviduct. In a later manner, vaginitis condition affects the movement and blockage of oviduct as the vital reproductive organs for conception. Anas et al. (2016) reported that microorganisms found from the female reproductive tract of infertile couples in Mojokerto, East Java, Indonesia, were dominated by $S$. aureus (27\%) and E. coli (27\%), with the results of

* Corresponding Author:

Bayyinatul Muchtaromah

Department of Biology, Faculty of Science and Technology, Universitas Islam Negeri (UIN) Maulana Malik Ibrahim Malang, Indonesia

Phone: +6281231842316 Fax: +62341558933

e-mail: bayyinatul@bio.uin-malang.ac.id antibiotic sensitivity tests varying greatly. Through western blotting using s-IgA cervix uteri, S. aureus was found in the greatest number. Regarding this condition, it is necessary to solve the problem.

Recently, the use of herbal medicine has been widely adopted in developing and developed countries. Nearly four billion people ( $80 \%$ of the world's population) who live in developing countries depend on herbal medicinal products as the main source of health care and traditional medical practices involving herbal use are seen as an integral part of the culture in the community (Ekor, 2013). One of the Indonesian tribes, Madura, is known with traditional medicine recipes, "Subur Kandungan" herb. This herb is frequently used to increase fertility. The main ingredients of this recipe are $15 \%$ garlic (Allium sativum), $15 \%$ of temu mangga (Curcuma mangga), $12 \%$ of jeringau (Acorus calamus), and other materials up to $100 \%$. The bioactive contents of those herbal recipes are thought to be an important factor in improving female fertility.

Most of the problems associated with the use of traditional and herbal medicines appear primarily from the classification of many of these products as food or dietary supplements in several countries. Thus, evidence of the quality, efficacy, and safety of these herbal medicines is not needed before marketing. In addition, quality testing and production standards tend to be less strict or controlled and in some cases, many traditional health practitioners are not certified or licensed. Scientific information on the content of traditional medicines, appropriate dosage or composition are essential (Kasilo \& Trapsida, 2011).

Based on the explanation above, there has never been any research on phytochemical content and the use of a combination of A. sativum, C. mangga and A. calamus in different compositions and solvents (water and ethanol) as antibacterials against $S$. aureus and E. coli. Considering 
that E.coli and S. aureus are normal vaginal flora whose existence has a role in changing vaginal $\mathrm{pH}$ so that it cannot be completely switched off, it is important to conduct research on the potential combination of $A$. sativum, $C$. mangga and A. calamus as antibacterial

\section{Methods}

\section{Design of Research}

This research was an experimental study using descriptive analysis. The first stage was a qualitative phytochemical test, consisting of alkaloid, flavonoid, triterpenoid, steroid, saponin, and tannin test. The second stage was the inhibitory zone test with a concentration of $100 \%$ and 3 replications. The first combination $(\mathrm{C} 1)$ with the following composition was garlic: temu mangga: jeringau (36:36:28); the second combination (C2) (40:30:30); the third combination (C3) (35:40:45). The third stage was the minimum inhibitory concentration (MIC) and the minimum bactericidal concentration (MBC) assay, with concentrations of $0,0.39,0.78,1.56$, $3.13,6.25,12,25,50$, and $100 \%$, repetition of treatment three times.

\section{Materials}

Symplicia of the garlic bulb, the rhizome of temu mangga and jeringau were obtained from Balai Materia Medica, Malang, Indonesia. All the chemicals used in the present studies were of synthetic grade and were obtained from Merck Specialties Ltd. Bacterial strains E. coli and $S$. aureus culture was purchased from Microbiology Laboratory of Medical Faculty of Brawijaya University.

\section{Extraction by Maceration Method}

The procedure for the water and ethanol extraction of garlic, temu mangga and jeringau referred to the procedure on Centella asiatica which was previously described by (Muchtaromah et al., 2011; Muchtaromah, et al., 2016). $50 \mathrm{~g}$ of mix powder of garlic, temu mangga and jeringau was added to $200 \mathrm{~mL}$ of ethanol soaked for $24 \mathrm{~h}$, homogenized for $3 \mathrm{~h}$, and filtered with a whatman filter paper grade 1 (Sigma aldrich) on funnel Buchner. The obtained pulp was macerated three times with ethanol to get the clear filtrate. The maceration filtrate was concentrated at $40{ }^{\circ} \mathrm{C}$ using a rotary evaporator until a thick extract was obtained. The same procedure was carried out on water solvent. The extraction percentage was calculated using the equation (Ahmad, 2009):

$$
\% \text { Extraction }=\frac{m_{1}-m_{2}}{m_{1}} \times 100
$$

\footnotetext{
Where:

$\mathrm{m}_{1}=$ mass of the sample before extraction

$\mathrm{m}_{2}=$ mass of the sample after extraction
}

\section{Phytochemical Screening}

The phytochemical examination was performed using standard methods (Tiwari et al., 2011; Ibironke et al., 2010).

\section{Alkaloids Detection}

Each extract was dissolved in a solution of hydrochlo- followed by testing Minimum Inhibitory Concentration (MIC) and Minimum Bactericidal Concentration (KBM) to obtain the best combination in improving female fertility.

ric acid then filtered. Dragendroff test: Dragendroff reagent is added (Potassium Bismuth Iodide solution). If there is the formation of red precipitates, it indicates the presence of alkaloids. Mayer Test: Filtrate added Mayer reagent (Potassium Mercuric Iodide). If there is a yellow precipitate, it indicates the presence of alkaloids.

\section{Flavonoid Detection}

Wilstater Test: The sample put in a test tube, then dissolved in 1-2 $\mathrm{mL}$ of $50 \%$ hot methanol and added $\mathrm{Mg}$ metal and $0.5 \mathrm{~mL}$ of concentrated $\mathrm{HCl}$. If a red or orange solution is formed, it indicates flavonoids.

\section{Triterpene/steroid Detection}

Salkowski test: Extracts treated with chloroform and filtered. The filtrate is treated with several drops of concentrated sulfuric acid, shaken and silenced. The appearance of the golden yellow color indicates the presence of a triterpene.

Liberman Burchard test: Extracts treated with chloroform and filtered. The filtrate is treated with a few drops of acetic anhydride, boiled and cooled. Concentrated sulfuric acid is added. The formation of a brown ring at the intersection indicates the presence of phytosterols/steroid.

\section{Saponins Detection}

Foam Test: as much as $0.5 \mathrm{~g}$ of the extract is dissolved and shaken with $2 \mathrm{~mL}$ of water, if the resulting foam lasts for ten minutes, then it shows the presence of saponins.

\section{Tannins Detection}

$\mathrm{FeCl}_{3}$ Test: The sample is put into a test tube, then added with 2-3 drops of $1 \% \mathrm{FeCl}_{3}$ solution. If the solution is blackish green, it indicates the presence of tannin catechol compound and if it is blackish blue, it indicates the presence of tannin gallate compound.

\section{Antibacterial Activity of $S$. aureus and $E$. coli}

Inhibition zone diameters were measured by diffusion technique (Kirby Bauer method) with $100 \%$ concentration. Total $0.1 \mathrm{~g}$ of extract using (ethanol, water) individually was diluted with a total volume of $100 \mu \mathrm{L}$. Three sterile disc paper $(6 \mathrm{~mm})$ is inserted into the extract solution and saturated for 30 mins. Then the disk paper is inserted into the agar plate that has been dispersed with bacteria (S. Aureus, E. coli) (Vineetha et al., 2015). Clindamycin is used as a control. The classification of the inhibiting zones according to Pan et al. (2009) is classified as strong $(>6 \mathrm{~mm})$, good $(3-6 \mathrm{~mm})$ and weak $(0-3$ $\mathrm{mm})$.

MIC and MFC determination was performed using the microplate dilution method described by (Fatisa, 2013). Dilution stratification was then performed to produce fi- 
nal concentrations $(50 \%, 25 \%, 12.5 \%, 6.25,3.13 \%$, was inserted into 96-well plates and added with a $100 \mu \mathrm{L}$ bacterial suspension adjusted to the previous McFarland standard of 0.5. Steril Mueller Hinton Agar (MHA) is used as a control of sterility and microbial inoculum as a growth control. MIC is the lowest sample concentration that can inhibit the growth of microorganisms, which is seen after overnight incubation at $30{ }^{\circ} \mathrm{C}$ for $18 \mathrm{~h}$ to $20 \mathrm{~h}$. Bacterial growth was observed visually by comparing sample and control turbidity. MFC is the smallest concentration that can kill microbes, characterized by microbes

\section{Results}

\section{Extraction Result}

Extraction is the process of attracting the active compound of a material by a suitable solvent and method so that the desired result can be perfectly extracted. Each solvent will attract certain compounds based on the degree of polarity of the compound. The results of maceration of dried powder of garlic, temu mangga and jeringau are presented in table 1 .

Table 1. The yield of a combination of garlic, temu mangga and jeringau extract

\begin{tabular}{|c|c|c|c|c|}
\hline \multirow[b]{2}{*}{ Extract } & \multicolumn{2}{|c|}{ Water extract } & \multicolumn{2}{|c|}{ Ethanol extract } \\
\hline & $\begin{array}{c}\text { Yield (\%) } \\
(\mathbf{w} / \mathbf{w})\end{array}$ & Appearance & $\begin{array}{c}\text { Yield (\%) } \\
(\mathbf{w} / \mathbf{w})\end{array}$ & Appearance \\
\hline $\mathrm{C} 1$ & 11.360 & $\begin{array}{l}\text { Dark brown, } \\
\text { concentrated } \\
\text { liquid }\end{array}$ & 11.360 & $\begin{array}{c}\text { Dark brown, } \\
\text { concentrated } \\
\text { liquid }\end{array}$ \\
\hline $\mathrm{C} 2$ & 10.358 & $\begin{array}{l}\text { Dark brown, } \\
\text { concentrated } \\
\text { liquid }\end{array}$ & 11.473 & $\begin{array}{c}\text { Dark brown, } \\
\text { concentrated } \\
\text { liquid }\end{array}$ \\
\hline $\mathrm{C} 3$ & 7.960 & $\begin{array}{l}\text { Brown, } \\
\text { concentrated } \\
\text { liquid }\end{array}$ & 11.746 & $\begin{array}{c}\text { Dark brown, } \\
\text { concentrated } \\
\text { liquid }\end{array}$ \\
\hline
\end{tabular}

\section{Antibacterial Activity \\ Inhibitory Zone Against S. aureus}

Measurement of the diameter of the inhibition zone around the disk paper using Vernier Caliper. The formation of clear zones around disc paper indicated the inhibition of $S$. aureus growth (Figs. 1a and 1b). All composition of garlic, temu mangga and jeringau extracts had antibacterial activity against $S$. aureus which was indicated by the formation of inhibition zone. The inhibition zone in each treatment was presented in table 3.

Table 3 and Figure 1a showed that the inhibition zone of water extract from the largest in the sequence were C3 (7.81 $\pm 1.26 \mathrm{~mm} / \mathrm{strong}), \mathrm{C} 1(4.01 \pm 1.73 \mathrm{~mm} / \mathrm{good})$ and $\mathrm{C} 2$
$1.56 \%, 0.78 \%$, and $0.39 \%$ ). Then a $100 \mu \mathrm{L}$ extract sample cannot grow on plates, which signifies they have died at this concentration. Confirmation of MIC and MFC values is performed by with a streak plate of antibacterial test results in solid dilution.

\section{Data Analysis}

Data of the yield, phytochemical screening, inhibitory zone, minimum inhibitory concentration (MIC) and minimum fungicidal concentration (MFC) are presented descriptively in the form of figures and tables.

Table 1 shows that ethanol produces the highest yield of C3 (11.746\%) followed by C2 of $11.473 \%$, and C1 of $11.360 \%$ while water generates the highest yield of $\mathrm{C} 1$ $(11.360 \%)$ followed by C2 of $10.358 \%$, and C3 of $7.960 \%$. The yield of the extract should depend on the polarity of the solvent used during preparation. Moreover, the solubility of the natural products and the choice of solvent could also determine the yield. A further test is qualitative phytochemical screening.

\section{Phytochemical Screening}

The result of the phytochemical test of a combination of garlic, temu mangga and jeringau presented at table 2 .

The phytochemical test determined the secondary metabolite. Phytochemical test in this study resulted in triterpenoid content in the water extract whereas alkaloid, flavonoids, triterpenoids content in ethanol extract.

$(3.26 \pm 1.36 \mathrm{~mm} /$ good $)$. Clindamycin $(\mathrm{C}+)$ has the greatest inhibition zone $(33.75 \pm 5.26 \mathrm{~mm} / \mathrm{strong})$. In the ethanol extract, the largest of inhibition zone was C3 (10.71 \pm 1.0 $\mathrm{mm} / \mathrm{strong})$, followed by $\mathrm{C} 1(9.92 \pm 0.5 \mathrm{~mm} / \mathrm{strong})$ and C2 (4.61 $2.0 \mathrm{~mm} /$ good) (Tab. 3 and Fig. 1b). Clindamycin as a positive control has the largest inhibitory zone $(37.09 \pm 0.6 \mathrm{~mm} / \mathrm{strong})$. According to Pan et al. (2009), the inhibition zone of $0-3 \mathrm{~mm}$ includes the weak category, 3-6 $\mathrm{mm}$ good, and $\geq 6 \mathrm{~mm}$ strong.

Table 2. Phytochemical screening of combination of garlic, temu mangga and jeringau

\begin{tabular}{|c|c|c|c|c|c|c|c|}
\hline \multirow[t]{2}{*}{ Group of compound } & \multirow[t]{2}{*}{ Reagent test } & \multicolumn{3}{|c|}{ Water extract } & \multicolumn{3}{|c|}{ Ethanol extract } \\
\hline & & C1 & $\mathrm{C2}$ & C3 & C1 & $\mathbf{C 2}$ & C3 \\
\hline \multirow[t]{2}{*}{ Alkaloid } & Dragendorff & - & - & - & + & + & + \\
\hline & Mayer & - & - & - & - & - & - \\
\hline Flavonoid & Wilstater & - & - & - & + & + & + \\
\hline Triterpenoid & Salkowski & + & + & + & + & + & + \\
\hline Steroids & Lieberman-Burchard & - & - & - & - & - & - \\
\hline Saponin & Foam & - & - & - & - & - & - \\
\hline Tannin & $\mathrm{FeCl}_{3}$ & - & - & - & - & - & - \\
\hline
\end{tabular}


Table 3. Inhibition zone of water and ethanol extract against S. aureus

\begin{tabular}{cccccc}
\hline \multirow{2}{*}{ No. } & Group & Water extract & Categorized & Ethanol extract & $\begin{array}{c}\text { Categorized by Pan } \\
\text { et al. (2009) }\end{array}$ \\
\cline { 3 - 6 } & & $4.01 \pm 1.73$ & Good & $9.92 \pm 0.5$ & Strong \\
1. & C1 $(28: 36: 36)$ & $3.26 \pm 1.36$ & Good & $4.61 \pm 2.0$ & Good \\
2. & C2 $(30: 30: 40)$ & $7.81 \pm 1.26$ & Strong & $10.71 \pm 1.0$ & Strong \\
3. & C3 $(25: 40: 35)$ & Strong & $37.09 \pm 0.6$ & Strong \\
4. & C+ (Clindamycin) & $33.75 \pm 5.26$ & & &
\end{tabular}
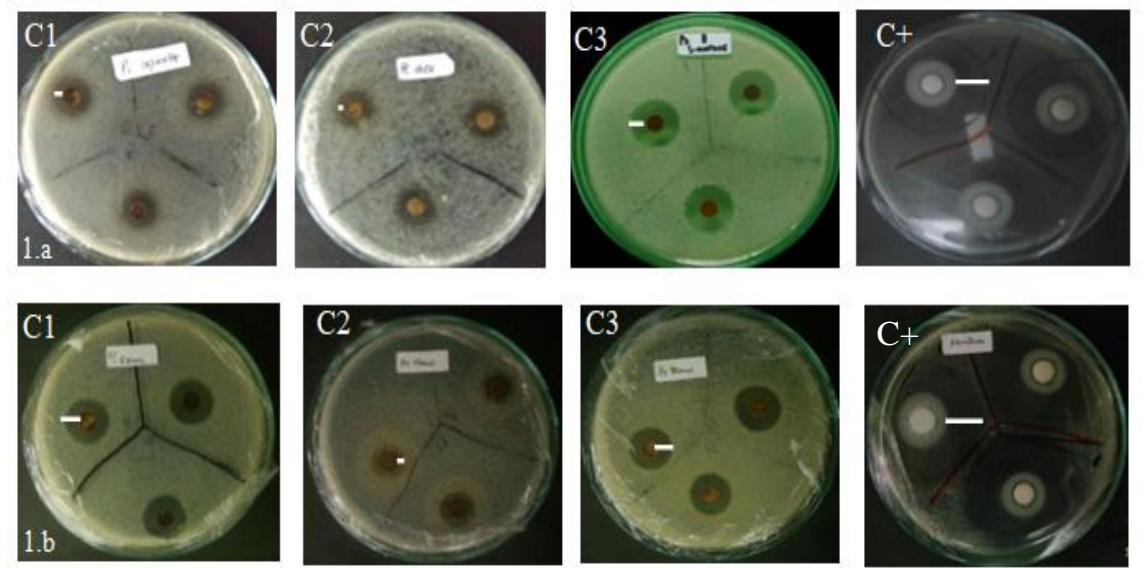

Figure 1. Inhibition zone against S.aureus(a) on water extract C1 $(4.01 \pm 1.73 \mathrm{~mm}), \mathrm{C} 2(3.26 \pm 1.36 \mathrm{~mm}), \mathrm{C} 3(7.81 \pm 1.26 \mathrm{~mm}), \mathrm{C}+(33.75 \pm 5.26 \mathrm{~mm}(\mathrm{~b})$ on ethanol extract $\mathrm{C} 1(9.92 \pm 0.5 \mathrm{~mm}), \mathrm{C} 2(4.61 \pm 2.0 \mathrm{~mm}), \mathrm{C} 3(10.71 \pm 1.0 \mathrm{~mm}) \mathrm{C}+(37.09 \pm 0.6 \mathrm{~mm})$.

\section{MIC and MBC Value Against $S$. aureus}

Table 4 presented that bacterial control $(\mathrm{C}+)$ had the highest total of a bacterial colony. MIC value of $\mathrm{C} 1$ and C3 water extract on $S$. aureus was found at concentration $0,39 \%$ with total colony $\mathrm{C} 1\left(6.50 \times 10^{12}\right)$ and $\mathrm{C} 3(9.76$ $\mathrm{x} 10^{10}$ ) and $\mathrm{MBC}$ was at concentration $0,78 \%$. MIC value of $\mathrm{C} 2$ with total colony $4.93 \times 10^{10}$ was got at concentrations of $1.56 \%$ and $\mathrm{MBC}$ at concentration $3.13 \%$.

The MIC value of ethanol extract was obtained consecutively by $\mathrm{C} 1\left(5.9 \times 10^{8}\right), \mathrm{C} 2\left(6.9 \times 10^{8}\right)$ and $\mathrm{C} 3$ $\left(1.87 \times 10^{9}\right)$ at concentrations of $0.39 \%$ and $\mathrm{MBC}$ at a concentration of $0.78 \%$. The most effective MIC values were found in $\mathrm{C} 1$ with the number of colonies of $5.9 \times 10^{8}$

Table 4. MIC and MBC value of water and ethanol extract against S. aureus

\begin{tabular}{|c|c|c|c|c|c|c|}
\hline \multirow{3}{*}{$\begin{array}{c}\text { The } \\
\text { concentration of } \\
\text { test sample }\end{array}$} & \multicolumn{6}{|c|}{ Total colony account of S.aureus (CFU/mL) } \\
\hline & \multicolumn{3}{|c|}{ Water extract } & \multicolumn{3}{|c|}{ Ethanol extract } \\
\hline & $\mathrm{C1}$ & $\mathrm{C2}$ & C3 & C1 & $\mathrm{C} 2$ & $\mathrm{C3}$ \\
\hline $0 \%(\mathrm{C}+)$ & $1.29 \times 10^{14}$ & $1.42 \times 10^{14}$ & $2.05 \times 10^{14}$ & $1.29 \times 10^{14}$ & $1.42 \times 10^{14}$ & $2.05 \times 10^{18}$ \\
\hline $0.39 \%$ & $6.5 \times 10^{12}$ & $1.36 \times 10^{14}$ & $9.76 \times 10^{10}$ & $5.9 \times 10^{8}$ & $6.9 \times 10^{8}$ & $1.87 \times 10^{9}$ \\
\hline $0.78 \%$ & 0 & $1.08 \times 10^{13}$ & 0 & 0 & 0 & 0 \\
\hline $1.56 \%$ & 0 & $4.93 \times 10^{10}$ & 0 & 0 & 0 & 0 \\
\hline $3.13 \%$ & 0 & 0 & 0 & 0 & 0 & 0 \\
\hline $6.25 \%$ & 0 & 0 & 0 & 0 & 0 & 0 \\
\hline $12.5 \%$ & 0 & 0 & 0 & 0 & 0 & 0 \\
\hline $25 \%$ & 0 & 0 & 0 & 0 & 0 & 0 \\
\hline $50 \%$ & 0 & 0 & 0 & 0 & 0 & 0 \\
\hline $100 \%(\mathrm{C}-)$ & 0 & 0 & 0 & 0 & 0 & 0 \\
\hline
\end{tabular}

Inhibitory Zone Against $E$. coli

The water and ethanol extract of A. sativum, $C$. mangga, and $A$. calamus had an antibacterial activity to $E$. coli as shown in the table 5 and figures $2 \mathrm{a}, 2 \mathrm{~b}$.

Table 5 and figure $2 \mathrm{a}$ indicated that the highest inhibition zone of water extract was got by $\mathrm{C} 3$ of 3.78 $\mathrm{mm}$, followed by $\mathrm{C} 1$ of $3.58 \mathrm{~mm}$, and $\mathrm{C} 2$ of $3.11 \mathrm{~mm}$.
Clindamycin as a positive control had an inhibition zone of $29.42 \mathrm{~mm}$. The highest inhibition zone of ethanol extract to $E$. coli was C3 of $4.26 \mathrm{~mm}$, followed by $\mathrm{C} 1$ of $3.65 \mathrm{~mm}, \mathrm{C} 2$ of $3.26 \mathrm{~mm}$. Clindamycin had an inhibition zone of $33.75 \mathrm{~mm}$ (Tab. 5 and Fig. 2b). 
Table 5. Inhibition zone of water and ethanol extract against E. coli

\begin{tabular}{ccccc}
\hline & & \multicolumn{2}{c}{ Inhibition Zone (mm) \pm SD } \\
\cline { 3 - 5 } No & Group & Water extract & Categorized & Ethanol extract \\
\hline 1. & C1 $(28: 36: 36)$ & $3.58 \pm 0.86$ & Good & $3.65 \pm 0.4$ \\
2. & C2 $(30: 30: 40)$ & $3.11 \pm 0.82$ & Good & $2.62 \pm 0.3$ \\
3. & C3 $(25: 40: 35)$ & $3.78 \pm 0.43$ & Good & $4.26 \pm 0.5$ \\
4. & C+ (Clindamycin) & $29.42 \pm 1.97$ & Strong & Good \\
Weak & Good & Strong \\
\hline
\end{tabular}
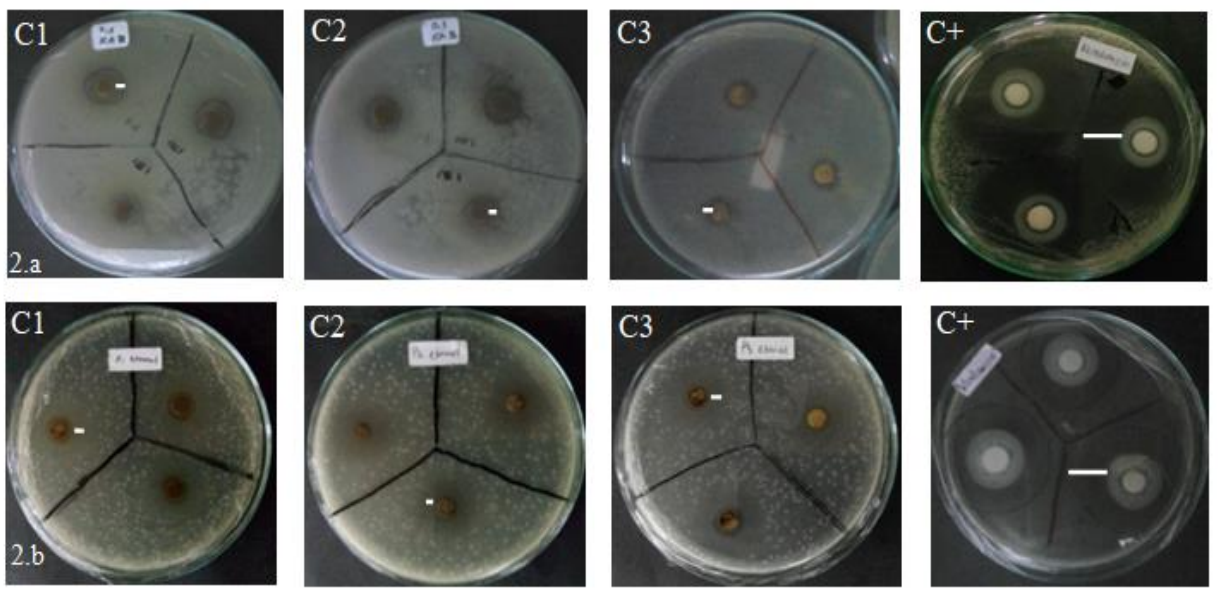

Figure 2. Inhibition zone against E. coli. (a). on water extract $\mathrm{C} 1(3.58 \pm 0.86 \mathrm{~mm}), \mathrm{C} 2(3.11 \pm 0.82 \mathrm{~mm}), \mathrm{C} 3(3.78 \pm 0.43 \mathrm{~mm}), \mathrm{C}+(29.42 \pm 1.97 \mathrm{~mm}$. (b) on ethanol extract C1 $(3.65 \pm 0.4 \mathrm{~mm})$ and $\mathrm{C} 2(2.62 \pm 0.3 \mathrm{~mm}) \mathrm{C} 3(4.26 \pm 0.5 \mathrm{~mm}), \mathrm{C}+(30.29 \pm 2.1 \mathrm{~mm})$.

\section{MIC and MBC Value Against E.coli}

MIC and MBC value of water extract to $E$. coli were found at $25 \%$ and $50 \%$ concentrations, while the most effective result was found on $\mathrm{C} 1$ with the smallest bacterial colony $\left(1.08 \times 10^{10}\right)$. The most effective MIC and MBC in ethanol extract was C3 (MIC 0.39\% \& MBC
$0.78 \%$ ) with total colony $9.7 \times 10^{9}$, followed by $\mathrm{C} 2$ (MIC $1.56 \%$ \& MBC $3.13 \%$ ) and $\mathrm{C} 1$ (MIC $6.25 \%$ \& $\mathrm{MBC}$ $12.5 \%$ ) (Tab. 5). It also could be seen that the higher the concentration of the extract the lower the number of bacteria.

Table 5. MIC and MBC value of water and ethanol extracts against E. coli

\begin{tabular}{|c|c|c|c|c|c|c|}
\hline \multirow{3}{*}{$\begin{array}{c}\text { The } \\
\text { concentration of } \\
\text { test sample }\end{array}$} & \multicolumn{6}{|c|}{ Total Colony Account E. coli $(\mathrm{CFU} / \mathrm{mL})$} \\
\hline & \multicolumn{3}{|c|}{ Water extract } & \multicolumn{3}{|c|}{ Ethanol extract } \\
\hline & C1 & C2 & C3 & C1 & C2 & C3 \\
\hline $0 \%(\mathrm{C}+)$ & $2.14 \times 10^{18}$ & $2.35 \times 10^{18}$ & $2.64 \times 10^{18}$ & $2.14 \times 10^{18}$ & $2.35 \times 10^{17}$ & $2.64 \times 10^{18}$ \\
\hline $0.39 \%$ & $2.04 \times 10^{14}$ & $1.57 \times 10^{14}$ & $1.27 \times 10^{14}$ & $1.41 \times 10^{18}$ & $1.19 \times 10^{17}$ & $9.70 \times 10^{9}$ \\
\hline $0.78 \%$ & $1.35 \times 10^{14}$ & $1.43 \times 10^{14}$ & $1.24 \times 10^{14}$ & $1.18 \times 10^{14}$ & $1.28 \times 10^{13}$ & 0 \\
\hline $1.56 \%$ & $1.33 \times 10^{14}$ & $1.33 \times 10^{14}$ & $1.17 \times 10^{14}$ & $1.37 \times 10^{13}$ & $8.70 \times 10^{9}$ & 0 \\
\hline $3.13 \%$ & $1.28 \times 10^{14}$ & $1.33 \times 10^{14}$ & $1.07 \times 10^{14}$ & $8.40 \times 10^{12}$ & 0 & 0 \\
\hline $6.25 \%$ & $1.17 \times 10^{14}$ & $1.28 \times 10^{14}$ & $8.20 \times 10^{13}$ & $1.23 \times 10^{10}$ & 0 & 0 \\
\hline $12.5 \%$ & $8.06 \times 10^{12}$ & $6.70 \times 10^{13}$ & $7.70 \times 10^{12}$ & 0 & 0 & 0 \\
\hline $25 \%$ & $1.08 \times 10^{10}$ & $1.60 \times 10^{10}$ & $1.60 \times 10^{10}$ & 0 & 0 & 0 \\
\hline $50 \%$ & 0 & 0 & 0 & 0 & 0 & 0 \\
\hline $100 \%(\mathrm{C}-)$ & 0 & 0 & 0 & 0 & 0 & 0 \\
\hline
\end{tabular}

\section{Discussion}

Table 1 shows that ethanol extract produces higher yields than water extracts. This is probably due to the high polarity of ethanol solvents that can attract various constituents of plants rather than water (Paulsamy \& Jeeshna, 2011). There are many steps to get phytochemicals from plants such as milling, homogenization, and extraction. Among these steps, extraction is the main step to restore and isolate phytochemicals from plant material. Extraction efficiency is influenced by the chemical properties of phytochemicals, the extraction method used, the particle size of the sample, the solvent used, and the presence of disturbing substances. Extraction results depend on the solvent with various polarity, $\mathrm{pH}$, temperature, extraction time, and sample composition. Under the same extraction time and temperature, the solvent and sample composition are known as the most important parameters (Mostafa et al., 2018).

The difference in yield due to each combination has a different composition and solvent. In this study, ethanol extract was able to attract alkaloids, flavonoids, and triterpenoids while water extract was the only 
triterpenoid. This showed that ethanol extracts are more effective in attracting active ingredients present in all combination. Most of the secondary metabolites in garlic, temu mangga and jeringau are found in higher amounts in ethanol extracts than other solvents. However, flavonoids and alkaloids are rich in ethanol extract. This explains that the level of polarity and nature of species play a major role in extracting secondary metabolites (Ghasemzadeh, 2011; Muchtaromah et al., 2017).

Das et al. (2010) reported that water is a universal solvent, used to extract plant products with antimicrobial activity. Although traditional medicine mainly uses water, plant extracts from organic solvents have been known to provide more consistent antimicrobial activity compared to water extracts. Likewise, flavonoids which dissolve in water (mostly anthocyanins) have not acted as antimicrobials and phenolics which dissolve in water are only important as antioxidant compounds. Kanduč et al. (2016) revealed that water is a solvent, that capable of dissolving many types of chemicals, especially hydrophilic and polar substances. The solubility of a substance in water was determined by the ability of the agent to match the strength of the electric attraction (intermolecular dipole) between water molecules. If a substance was unable to match the attraction between the water molecules, the molecules of the substance were insoluble and will settle in water.

Muhamad et al. (2014) notified that ethanol was a polar solvent, which means it could dissolve polar compounds and ethanol could be mixed with water that was also polar. The important properties were polarities and polar groups of a compound. In principle, a material would be easily soluble in the same solvent polarity so that it would affect the physicochemical properties of the resulting extraction, next ethanol more easily penetrates cell membranes to extract intracellular material from plants. Whereas almost all active compounds of plants that have antimicrobial activity are aromatic or saturated organic compounds, they are most often obtained through initial extraction of ethanol or methanol (Wang, 2010)

Do et al. (2014) revealed that ethanol was a universal solvent so that both polar and nonpolar compounds could be extracted optimally, alongside ethanol being an easyto-obtain and harmless solvent such as methanol. Ethanol had a low toxicity level and a versatile solvent. Sinambela (2003) stated that the extraction of medicinal plant material with ethanol solvent into a liquid extract or dried extract was mostly done for the purpose of standardization of herbal medicine.

Table 3 and figure 2 inform that the highest inhibition zone of both extracts against $S$. aureus is C3 (35:40:45), followed by $\mathrm{C} 1$ (36:36:28) and C2 (40:30:30), while the inhibitory value of ethanolic extract showed higher results than water extract. This result also was judged by better MIC value of ethanolic extract compare to water extract (Tab. 4). The most effective MIC value was found in the $\mathrm{C} 1 /$ ethanolic extract with the number of colonies of 5.9 $\mathrm{x} 10^{8}$. The number of these colonies was close to the number of the existence of normal flora that needs to be maintained. Sánchez et al. (2012) mention the normal number of flora bacteria that need to be maintained ie $10^{8}$ $10^{9}$ colonies per mL, Pursuant to Muhamad et al. (2014), the same plant species with different compositions in each combination might produce secondary metabolite compounds in different concentrations and activities or contain different chemical group structures.

This was similar with research of Baljeet et al. (2015), on the antimicrobial test of individual and combination of ethanolic extract from cumin, ginger, and garlic against bacterial strains of Bacillus subtilis, Pseudomonas fluroscens, Salmonella typhi and fungal strains of Candida albicans and Rhizopus azygosporus. Agar well diffusion assay for antimicrobial activity yielded the inhibitory zone of 12.8 to $18.3 \mathrm{~mm}$ diameter for cumin, 11.5 to $16.3 \mathrm{~mm}$ diameter for ginger and 16.8 to $19.3 \mathrm{~mm}$ diameter for garlic extract indicating that garlic was the most effective spice in inhibiting the microbial growth. The combined extracts showed inhibition zones ranging from 12.3 to $19.6 \mathrm{~mm}$ in diameter against bacteria and 15.6 to $19.6 \mathrm{~mm}$ against fungus. The combined extract of cumin, ginger, and garlic was found to be most effective in inhibiting the microbial growth. The MIC of individual extracts was $12.5 \mathrm{mg} / \mathrm{ml}$ against all the tested microorganisms. The MIC of combined extracts fluctuated from 3.8 to $6.7 \mathrm{mg} / \mathrm{ml}$ and the most sensitive microbial species in relation to the MIC of combined extracts was $S$. typhi.

Inhibition of bacterial growth from a combination of water and ethanol extract of garlic, temu mangga and jeringau on $S$. aureus was still far in comparison with positive control (clindamycin). Clindamycin produced a wide inhibitory zone, but the ability of clindamycin to kill $S$. aureus was low, because there was still bacterial growth around the inhibitory zone, meaning that clindamycin could inhibit the bacterial growth only (bacteriostatic). The inhibition zone resulting from the combination of water and ethanol extract was radical because there were no bacteria growing around the clear zone. This means that the combination of water and ethanol extracts could kill S. aureus (bactericide). In pursuance of Jennie (2017), clindamycin as an antibacterial inhibited the growth or reproduction of bacteria by inhibiting protein synthesis. S. aureus were normal flora bacteria whose existence could not be completely killed, it was more appropriate to use concentrations that could inhibit bacterial growth so that the presence of normal flora bacteria could be maintained (Balasubramanian et al., 2017). MIC and MBC values could provide appropriate concentration information in treating infections, adjusted for the purpose of use.

The content of some active compounds in ethanol extract allows the inhibition zone to be greater than the water extract (Tab. 2\&3). The presence of these active compounds can inhibit or damage vital cell parts such as cell walls, and organelles that are presented in the bacterial cytoplasm. In accordance with Tiwari et al. (2011) triterpenoid compounds could work as antifungal, insecticide, antibacterial, and antiviral. The mechanism of triterpenoid as an antibacterial was to react with the outer membrane of the bacterial cell wall, forming a strong polymer bond so that it could lead to the destruction of the membrane which was the entrance of the compound entrance. Thus there was a decreasing in permeability of 
bacterial cell wall and cause bacterial cell deficiency, hence bacterial growth was inhibited or dead.

Several studies on the relationship between flavonoid structure and antibacterial activity have been carried out and this is in close agreement. Also, many research groups have tried to explain the antibacterial mechanism of the actions of selected flavonoids. The activity of quercetin, for example, has at least partially been linked to inhibition of DNA gyrase. Besides, it has been concluded that sophoraflavone $\mathrm{G}$ and (-)- epigallocatechin gallate inhibit the function of the cytoplasmic membrane and that licochalcones $\mathrm{A}$ and $\mathrm{C}$ inhibit energy metabolism. Other flavonoids whose mechanism of action have been investigated include robinetin, myricetin, apigenin, routine, galangin, 2,4,2 x-trihydroxy-5x-methyl chalcone and lonchocarpol A (Cushnie et al., 2005).

Cushnie et al. (2014) reported that the mechanism of antibacterial action (MOA) of alkaloids in the classes of indolizidine, isoquinoline, quinolone, agelasine and polyamine was investigated. In the class indolizidine, alkaloid pergularinin and tylophorinidine, it works by inhibiting nucleic acid synthesis, because they inhibit the enzyme dihydrofolate reductase in cell-free tests. In the isoquinoline class, two MOAs have been found. Studies with benzophenanthridine and protoberberine isoquinolines show that it works by interfering with the Z-ring and inhibiting cell division. Evidence shows that sanguinarine and berberine (a) bind to FtsZ, (b) inhibit FtsZ GTPase activity, (c) inhibit $\mathrm{Z}$ ring formation and (d) induce cell extension without affecting DNA replication, nucleoid segregation or membrane structure and without inducing an SOS response. Overexpression and underexpression studies also support this mechanism. Researchers working with isoquinoline undermine phenanthridine prove that these alkaloids act by inhibiting nucleic acid synthesis through type I topoisomerase inhibition in cell-free tests.

Naturally, quinolone alkaloids do not have a 3carboxyl group which allows synthetic quinolones such as fluoro-quinolones to inhibit type II topoisomerase enzymes. Research using alkyl methyl quinolones proves that this is a respiratory inhibitor because they reduce the consumption of $\mathrm{O}_{2}$ in the bacteria treated but do not affect $3 \mathrm{H}$ uptake. Agelasines are a class of alkaloids from the sea sponge Agelas. Overexpression and affinity studies using alkaloid agelasine D indicate that it works by inhibiting the enzyme BCG 3185c (dioxygenase), thus disrupting bacterial homeostasis (Tavares et al., 2014).

Based on Table 3 \& Figure 2, E. coli (gram negative) resulted in a smaller inhibitory zone than $S$. aureus (gram

\section{Acknowledgment}

This work was supported by Faculty of Science and Technology Funding, Universitas Islam Negeri Maulana Malik Ibrahim Malang, Indonesia.

\section{References}

Ahmad, A., Abbas, F. M., Alkarkhi, Hena, S., \& Khim, L. H. (2009). Extraction, Separation, and Identification of Chemical Ingredients of Elephantopus scaber L. Using Factorial Design of Experiment. International Journal of Chemistry, 1(1), 36-49. positive). Jawetz (2005) revealed that the structure of the cell wall of gram-positive bacteria was simpler namely single-layered with a low lipid content (1-4\%) making it easier for bioactive ingredients to enter the cell. Gramnegative bacteria are more complex, namely three-layered consisting of an outer layer of lipoprotein, the middle layer of lipopolysaccharide which acts as a barrier to the entry of antibacterial bioactive ingredients, and an inner layer of peptidoglycan with high lipid content (11-12\%). In accordance with Muheim et al. (2017), gram-positive bacteria did not have lipopolysaccharides, so that hydrophobic antibacterial compounds could pass through gram-positive cell wall through passive diffusion. Dewi (2013) stated that the acidic acid found in the cell wall of gram-positive bacteria was a water-soluble polymer, which served as a positive ion transport to get out or enter. This water-soluble nature signified that the cell wall of gram-positive bacterial was polar. Polar properties facilitated triterpenoid compound from water extract penetrated gram-positive bacteria cell wall easily.

The greatest MIC value of water extract on E. coli was found at $\mathrm{C} 1\left(1.08 \times 10^{10}\right)$ with concentrations of $25 \%$, whilst the most effective values of extract ethanol on E.coli was obtained at $\mathrm{C} 3\left(9.7 \times 10^{9}\right)$ with a concentration of $0.39 \%$ (Tab. 5). The MIC and MBC values were affected by the solvent used. The water was polar, so only the attracted compounds were polar, ie triterpenoid, whereas $E$. coli was a gram-negative bacteria composed of complex cell walls. Lind et al (2015) revealed that the outer membrane of $E$. coli contained $20 \%$ lipid which was nonpolar. Differences in the nature of polarity between bacterial cell walls and triterpenoid caused MIC and MBC ethanol extracts more effective than water extracts. The number of active compounds attracted to the ethanol solvent caused the MIC and MBC values to be more effective.

Brooks et al. (2008) reported the number of active compounds in the extract was increasing the ability to inhibit bacterial growth. Aside from, the MIC and MBC values indicated by bacterial colonies were inversely proportional to the concentration of the extract. The higher concentration of extract showed lower bacterial count. In accord with Mostafa et al. (2018) the higher the extract the higher the potential to inhibit the bacteria, thus at high concentrations, the number of bacterial colonies decreased. The concentration factor, the type of antimicrobial materials and solvents also determined the ability to inhibit bacterial growth.

Anas, M., Wiyasa, W. A., Riyanto, S., Sardjono, T. W. Aulani'am, \& Prawiro, S. R. (2016). Microorganism spectrum of nonspecific vaginitis in women of infertile couples recognized by $\mathrm{s}-\operatorname{IgA}$ uterine cervix secretion. Asian Pacific Journal of Reproduction, 5(6), 467-47. doi:org/10.1016/j.apjr.2016.10.007

Balasubramanian, D., Harper, L., Hopsin, B. \& Torres, V.J. (2017) Minireview. Staphylococcus aureus pathogenesis in diverse host environments. Pathogens and Disease, 75(1), 1-1 3.

Baljeet, S. Y., Simmy, G., Ritika, Y., \& Roshanlal, Y. (2015). Antimicrobial activity of individual and combined extracts of selected spices against some pathogenic and food spoilage microorganisms. International Food Research Journal, 22(6), 2594-2600. 
Brooks, G. F., Butel, J. S., \& Morse, S. A. (2008). Mikrobiologi Kedokteran. Edited by Jawetz, Melnick, and Adelberg.23rd edition. Jakarta: EGC. Cushnie, T. P. M., \& Lamb, A. J. (2005). Review. Antimicrobial activity of flavonoids. International Journal of Antimicrobial Agents, 26, 343-356.

Cushnie, T. P. M., Cushnie, B., \& Lamb, A. J. (2014). Alkaloids: An overview of their antibacterial, antibiotic-enhancing and antivirulence activities. Int J Antimicrob Agents, 44, 377-386. doi:org/10. 1016/j.ijantimicag.2014.06.001

Das, K., Tiwari, R. K. S., \& Shrivastava, D. K. (2010). Techniques for evaluation of medicinal plant products as antimicrobial agent: Current methods and future trends. Journal of Medicinal Plants Research, 4(2), 104-111.

Dewi, A. K. (2013). Isolasi, Identifikasi dan Uji Sensitivitas Staphylococcus aureus terhadap Amoxicillin dari Sampel Susu Kambing Peranakan Ettawa ( PE ). Jurnal Sain Veteriner, 31(2), 138-150. Divya, G. A. (2015). Study to Detect ESBL producing Escherichia coli Isolates From Women with Genital Tract Infection. Indian Journal Of Applied Research, 5 (8).

Do, Q. D., Angkawijaya, A. E., Tran-Nguyen, P. L., Huynh, L. H., Soetaredjo, F. E., Ismadji, S., \& Ju,Y.(2014). Effect of extraction solvent on total phenol content, total flavonoid content, and antioxidant activity of Limnophila aromatic. Journal of Food and Drug Analysis, 22(3), 296-302.

Ekor, M. (2013). The growing use of herbal medicines: issues relating to adverse reactions and challenges in monitoring safety. Front Pharmacol, 4, 177.

Fatisa, Y. (2013). Daya Antibakteri Estrak Kulit Dan Biji Buah Pulasan(Nephelium mutabile) terhadap Staphylococcus aureus dan Escherichia coli secara In Vitro. Jurnal Peternakan, 10 (1).

Ghasemzadeh, A., Jaafar, H., \& Rahmat, A. (2011). Effects of solvent type on phenolics and flavonoids content and antioxidant activities in two varieties of young ginger (Zingiber officinale Roscoe.) extracts. J Med Plant Res, 5(7), 1147-1154.

Ibironke, A. A., Sarah, O. N., \& Adewale, A. (2010). Anti-microbial activity and phytochemical screening of five selected seeds from Nigeria. Int J Biomed Pharm Sci, 4, 104-106.

Jawetz, E., Melnick, J. L., \& Adelberg, E. A. (2005). Mikrobiologi untuk Profesi Kesehatan (Review of Medical Microbiology) Diterjemahkam oleh H. Tomang (pp. 317-318). Jakarta: EGC.

Jennie, H. K. (2017). 141 - Macrolides, Ketolides, Lincosamides, and Streptogramins. Anti-infective Therapy. In: Bryskier A. Infectious Diseases (4th Edition). Elsevier. 2, 1217-1229.e1. doi:org/ 10.1016/B978-0-7020-6285-8.00141-6

Kanduč, M., Schlaich, A., Schneck E., \& Netz, R. R. (2016). Interactions between Hydrophilic and Hydrophobic Surfaces. Langmuir, 32 (35), 8767-8782. doi: 10.1021/acs. langmuir. $6 \mathrm{~b} 01727$

Kamazeri, T. S., Samah, O. A., Taher, M., Susanti, D., \& Qaralleh, H. (2012). Antimicrobial activity and essential oils of Curcuma aeruginosa, Curcuma mangga, and Zingiber cassumunar from Malaysia. Asian Pac J Trop Biomed, 5, 202-209.

Kasilo O., \& Trapsida, J. M. (2011). Decade of African traditional medicine, 2001-2010. Afr. Health Mon.(Special Issue), 14, 25 31

Lind, T. K., Wacklin, H., Schiller, J., Moulin, M., Haertlein, M., \& Pomorski, T. G. (2015). Formation and Characterization of Supported Lipid Bilayers Composed of Hydrogenated and Deuterated Escherichia coli Lipids. PLoS ONE, 10 (12), 0144671. doi:10.1371/ journal.pone. 014467

Mostafa, A. A., Abdulaziz, A. A., Almaary, K. S., Dawoud, T. M., Sholkamy, E. N., \& Bakri, M. M. (2018). Antimicrobial activity of some plant extracts against bacterial strains causing food poisoning diseases. Saudi Journal of Biological Sciences, $25,361-366$

Muchtaromah, B., Kiptiyah, K. \& Ad, T. K. (2011). Transaminase Enzyme and Liver Histological Profile of Mice Administered Extract of Pegagan (Centella asiatica (L.) Urban). Media Peternakan, 34, 88-92.

Muchtaromah, B., Ahmad, M., Suyono, S., Romaidi, R., Bahri, S. \& Kumalasari, H. P. (2016). Dosage and administration length of Centella asiatica (L.) Urban decrease the level of SOD and MDA and improve brain histological condition of rats. Jurnal Teknologi, 78, 57-61.

Muchtaromah, B., Ahmad, M., Sabdoningrum, E. K., Afifah, Y. M. \& Azzahra, V. L. (2017). Phytochemicals, Antioxidant and Antifungal Properties of Acorus calamus, Curcuma mangga, and Allium sativum in The Veterinary Medicine International Conference, KnE Life Sciences, 93-104. doi: 10.18502/kls.v3i6.1119

Muhamad, N., Muhamed, S. A., Yusoff, M. M., \& Gimbun, J. (2014). Influence of Solvent Polarity and Conditions on Extraction of Antioxidant, Flavonoids and Phenolic Content from Averrhoa bilimbi. Journal of Food Science and Engineering, 4,255-260. doi: 10.17265/2159-5828/2014.05.006

Muheim, C., Götzke, H., Eriksson, A. U., Lindberg, S., Lauritsen, I., Morten, H., Nørholm, H., \& Daley, D. O. (2017). Increasing the permeability of Escherichia coli using MAC13243. Scientific Report, 7 (17629), 1-11. doi:10.1038/s41598-017-17772-6

Pan, X., Chan, F., Wu, T., Tang, H., \& Zhao, Z. (2009). The acid, Bile Tolerance And Antimicrobial Property of Lactobacillus acidophilus NIT. J. Food Control, 20, 598-602

Paulsamy, S., \& Jeeshna, M. V. 2011. Preliminary phytochemistry and antimicrobial studies of an endangered medicinal herb Exacum bicolor Roxb. Res J Pharm Biol Chem Sci, 2(4), 447-457.

Razzak, M., Sabri A., Alaa, H., Al-Charrakh, \& AL-Greitty, B. H. (2011). Relationship Between Lactobacilli and Opportunistic Bacterial Pathogens Associated with Vaginitis. North American Journal of Medical Sciences, 3 (4).

Sinambela, J. S. (2003). Standarisasi Sediaan Obat Herba. Seminar Nasional Tumbuhan Obat Indonesia XXIII. Jakarta: Universitas Pancasila.

Sánchez, A., Rivera, A., Castillo, F., \& Ortiz, S. (2012). Cervical erosion as result of infectious vaginitis. European Journal of Experimental Biology, 2 (5).

Tavares, L., Zanon, G., Weber, A. D., Neto, A. T., \& Mostardeiro, C. P., (2014). Structure-activity relationship of benzophenanthridine alkaloids from Zan- thoxylum rhoifolium having antimicrobial activity. PLoS ONE, 9(5): e97000. doi: 10.1371/journal. pone. 0097000

Tiwari, P., Kumar, B., Kaur, M., Kaur, G., \& Kaur, H. (2011). Phytochemical screening, and Extraction: A Review. Internationale Pharmaceutica Sciencia, 1(1), 98-106.

Vineetha, N., Vignesh, R. A., \& Sridhar, D. (2015). Preparation, Standardization of Antibiotic Discs and Study of Resistance Pattern for First-Line Antibiotics in Isolates from Clinical Samples. International Journal of Applied Research, 1(11), 624631

Wang, G. X. (2010). In vivo anthelmintic activity of five alkaloids from Macleaya microcarpa (Maxim) Fedde against Dactylogyrus intermedius in Carassius auratus. Veterinary Parasitology, 171, $305-313$. 